\title{
ANALISIS GAYA BAHASA PADA FILM DILAN 1990 KARYA PIDI BAIQ
}

\author{
Yanti Pustika Sari ${ }^{1}$, Missriani ${ }^{2}$, Wandiyo $^{3}$ \\ Yanti.Pustika@gmail.com¹, Missriani05@yahoo.com², wwandiyo@gmail.com ${ }^{3}$ \\ Universitas PGRI Palembang
}

\begin{abstract}
Abstrak--Penelitian ini mengkaji ragam gaya bahasa dalam film Dilan 1990 karya Pidi Baiq, yang terdiri dari empat ragam gaya bahasa: gaya bahasa perbandingan, gaya bahasa pertentagan, gaya bahasa sindiran, dan gaya bahasa penegasan atau perulangan. Penelitian gaya bahasa dalam film Dilan 1990 karya Pidi Baiq menggunakan metode Deskriptif Kualitatif. Teknik pengumpulan data menggunakan teknik dokumentasi, simak dan catat. Teknik analisis data menggunakan deskriptif kualitatif. Berdasarakan hasil analisis ditemukan ragam gaya bahasa dengan keseluruhan 85 kutipan dialog yang menujukan gaya bahasa perbandingan terdapat 30 kutipan dialog, gaya bahasa pertentangan terdapat 5 kutipan dialog, gaya bahasa sindiran terdapat 28 kutipan dialog selanjutnya gaya bahasa penegasan atau perulangan terdapat 22 kutipan dialog. Berdasarkan penelitian gaya bahasa yang paling dominan yaitu gaya bahasa perbandingan.
\end{abstract}

Kata Kunci: Gaya bahasa, Film, Dilan

\section{LANGUAGE STYLE ANALYSIS ON DILAN MOVIE BY PIDI BAIQ}

\begin{abstract}
This study examines the variety of language styles in the film Dilan 1990 by Pidi Baiq, which consists of four different language styles: comparative language style, confrontational language style, satire language style, and affirmative or repetitive language style. Language style research in the 1990 film Dilan by Pidi Baiq uses a descriptive qualitative method. Data collection techniques using documentation techniques, refer to and record. The data analysis technique uses descriptive qualitative. Based on the results of the analysis found a variety of linguistic styles with a total of 85 dialogue quotations that show comparative language styles there are 30 dialogue quotes, conflicting language styles there are 5 dialogue quotations, allusive language styles there are 28 dialogue dialogues then there are 22 dialogue style affirmations or repetitions there are 22 dialogue quotes. Based on research the most dominant language style is comparative language style.
\end{abstract}

Key words: Language Style, Movie, Dilan

Artikel Diterima:01-07-2020 Artikel Disetujui:19-02-2021 Artikel Dipublikasi:28-02-2021

Corresponden Author: Yanti Pustika Sari_E-mail: Yanti.Pustika@gmail.com

DOI: http://dx.doi.org/10.31851/pembahsi.v11i1.43167

\section{PENDAHULUAN}

Gaya (style) tidak lain adalah cara mengukapkan diri sendiri, entah melaui bahasa, tingkah laku, berpakain dan sebagainya maka kita lalu mengenal 'gaya bahasa', 'gaya bertingkah', gaya berpakaian dan sebagainya (Satato,
2015). Menariknya sebuah karya seseorang tergantung dengan gaya (style) yang dituangkan dalam suatu karya sastra. Gaya bahasa memungkinkan kita dapat menilai pribadi, watak, dan kemampuan seseorang yang mempergunakan bahasa itu. Semakin 
baik gaya bahasanya, semakin baik pula penilaian orang terhadapnya; semakin buruk gaya bahasa seseorang, semakin buruk pula penilaian diberikan kepadanya (Keraf, 2010).

Gaya Bahasa (styleoflanguage) sebenarnya merupakan bagian dari pilihan kata atau diksi (diction) yang mempersoalkan cocok-tidaknya pemakaian kata. Frasa klausa kalimat atau mencakup wancana termasuk persoalan gaya bahasa (Satoto, 2012). Jadi dapat disimpulkan gaya bahasa adalah cara seorang pengarang yang mengaplikasikan suatu ide, atau gaya bahasa yang khas memperlihatkan kepribadian jiwa penulis dalam berkarya.

Ragam-ragam gaya bahasa; (1) gaya bahasa perbandingan terdiri dari, gaya bahasa perumpamaan/smile, metafora, personifikasi, alegori, eufemisme, metanonimia, asosiasi, hiperbola. (2) gaya bahasa pertentangan yang terdiri dari gaya bahasa litotes, paradoks, dan antitesis. (3) gaya bahasa sindiran terdiri dari gaya bahasa ironi, sinisme dan sarkasme. (4) gaya bahasa penegasaan atau perulangan yang terdiri dari gaya bahasa pleonasme, repetisi, antiklimaks, klimaks, elipsis, tatologi.

Bentuk-bentuk gaya bahasa banyak terdapat dalam kehidupan sehari hari, seperti dalam iklan, novel, puisi, teater, lagu, film dan sebagiannya. Semakin majunya perkembangan saat ini khususnya dalam ilmu teknologi, seseorang dapat menyampaikan ide serta karyanya melalui media visual/film. Dengan menggunakan media film, sebuah karya sastra dapat dinikmati secara lebih hidup dan hal yang dilukiskannya flash back.

Film atau gambar hidup merupakan gambar-gambar dalam frame demi frame diproyeksikan melalui lensa proyektor secara mekanis sehingga pada layar terlihat gambar itu hidup. Film bergerak dengan cepat dan bergantian sehingga memberikan visual yang kontinu (Arsyad, 2017). Masyarakat dapat menikmati sebuah karya sastra yaitu melalui film. Film tidak hanya hiburan semata, akan tetapi banyak hal yang bisa dipetik dari cerita film tersebut, baik itu dari segih budaya, nilai-nilai moral, dan bahasa yang digunakan.

Walau film pada dasarnya sebagai karya yang diperjual belikan atau sebagai bahan media hibuaran karena bentuknya visual, akan tetapi semakin majunya perkembangan Ilmu Pengetahuan Teknologi (IPTEK) yang berkembang begitu pesat khususnya di dunia pendidikan, maka dari itu film juga kerap digunakan sebagai alat media pembelajaran. Gaya bahasa pada film 
tentu berbeda dengan novel, cerpen, puisi, surat kabar, iklan dan lain-lain. Ragam gaya bahasa dalam film dapat diketahui melalui cara pengisahannya (Agustina, \& Mardiana, 2019) yaitu; dialog antar pemain, dialog batin, suratsurat, catatan harian, dan lain-lainnya. Dalam pengisahan inilah terdapat gaya bahasa yang bervariasi.

Bahasa merupakan alat sakti dalam pengembangan ilmu pengetahuan, teknologi, seni dan budaya (Suandi, 2020). Hal ini mengandung pengertian bahwa hampir diseluruh aspek kehidupan manusia memerlukan media pengembangan yang disebut bahasa (pemugkas 2012). Pada dasarnnya, bahasa memiliki fungsi-fungsi tertentu yang digunakan bedasarkan kebutuhan seseorang yakni sebagai alat mengekspresikan diri, komuniksi, sebagai alat untuk mengadakan integerasi dan beradaptsi sosial dalam lingkungan atau situasi tertentu, dan sebagai alat untuk melakukan kontrol sosial (Pemungkas, 2012).

Arsyad, (2017) meyatakan bahwa "Film atau gambar hidup merupakan gambar-gambar dalam frame demi frame doproyeksikan melalui lensa proyektor secara mekanis sehingga pada layar terlihat gambar itu hidup. Film bergerak dengan cepat dan bergantian sehingga memberikan visual yang kontinu." Film adalah media bersifat visual atau audio visual untuk menyampaikan pesan kepada sekelompok orang yang berkumpul disuatu tempat.

Menurut Keraf(2010) berpendapat Gaya atau khususnya gaya bahasa dikenal dalam retorika dengan istilah style. Kata style diturunkan dari kata latin slilus, yaitu semacam alat untuk menulis pada lempengan lilin. Keahlian menggunakan alat ini akan mempengaruhi jelas tidaknya tulisan pada pada lempengan tadi. Karena perkembangan itu, gaya bahasa atau style menjadi masalah atau bagian dari diksi atau pemilihan kata yang mempersoalkan cocok tidaknya pemakaian kata, frasa atau klausa tertentu untuk menghadapi situasi tertentu sebab itu, persoalan gaya bahasa meliputi semua hirarki kebahasaan: pilihan kata secara iduvidual, frasa, klausa, dan kalimat bahkan mencakupi pula sebuah wancana secara keseluruhan,

Sedangkan menurut Tarigan (2009) menyatakan bahwa "gaya bahasa adalah bahasa indah yang digunakan untuk meningkatkan efek dengan jalan memperkenalkan serta membandingkan suatu benda atau hal tertentu dengan benda atau hal lain yang digunakan untuk meningkatkan suatu benda atau hal 
tertentu denganbenda atau hal lain yang lebih umum".

Jenis-Jenis gaya bahasa

1. gaya bahasa perbandingan

2. gaya bahasa pertentagan

3. gaya bahasa sindiran

4. gaya bahasa penegasan atau perulangan

\section{METODE PENELITIAN}

Metode penelitian digunakan seseorang peneliti didalam usaha memecahkan masalah yang akan diteliti. Metode penelitian adalah cara yang digunakan oleh peneliti dalam mengumpulkan data penelitiannya. Dalam penelitian ini menggunakan metode deskriptif kualitatif. Deskriptif kualitatif merupakan salah satu dari jenis penelitian yang termasuk dalam jenis penelitian kualitatif.Data penelitan ini adalah CD film Dilan 1990 karya Pidi Baiq. Sumber peneliti ini adalah ini adalah film Dilan 1990 karya Pidi Baiq. Film ini dirilis pada tanggal 25, Januari 2018 yang di sutradarai oleh Fajar Bustomi dan Pidi Baiq, dengan durasi satu jam empat puluh menit empat puluh empat detik.). Pada penelitian ini peneliti mengunakan teknik dokumentsi, metode simak (pengamatan/observasi) melalui teknik catat.
Adapaun langkah-langkah peneliti menganalisis gaya bahasa dalam film Dilan 1990 karyaPidi Baiq sebagai berikut:

1. Peneliti menonton dan simak dengan teliti secara berulang-ulang setiap dialog yang ada di dalam film Dilan 1990 karyaPidi Baiq yang berbentuk $\mathrm{CD}$.

2. Peneliti mencatat semua dialog serta menganalisis jeni-jenis gaya bahasa yang terkandung dalam film Dilan 1990karya Pidi Baiq.

3. Peneliti membuat pembahasan yang sudah dianalisis pada sebelumnya.

4. Peneliti menarik kesimpulan dari data yang sudah dianalisis

\section{HASIL DAN PEMBAHASAN}

a. Gaya bahasa metafora Kutipan 1.

Di bus menuju pulang ke Bandung Lia (pada menit ke-35:11)

Lia kenapa (pada menit ke-35:12)

Lia (pada menit ke-35:13)

Itulah aslinya Benni, kalau kamu mau tahu kamu bisa menilainya sendiri lelaki macam apa yang tega marahin pacarnya dimuka umum. Dilan... (suara batin Milea) (pada menit ke- 35:22).

Gaya bahasa metafora adalah gaya bahasa perbandingan dua hal secara 
langsung yang memiliki sifat sama atau hampir sama dalam bentuk analogi dan tidak adanya konjungsi. Dalam kutipan dialog diatas, dapat diketahui gaya bahasa metafora terdapat pada penggunaan kata dimuka umum. Pada kata dimuka umum yang memiliki suatu makna yang menjelaskan bahwa beni pacarnya Milea memarahinya didepan orang banyak.

\section{Kutipan 2.}

Ayah milea memegang senapan angin sambil berbicang-berbicang

Milea. dengan Rani adiknya

Buat apa? (pada menit ke$01: 28: 15)$

Buat nembak tikus-tikus jalanan (pada menit ke-01:28:17)

Dalam kutipan dialog diatas, dapat diketahui gaya bahasa metafora terdapat pada penggunaan kata tikus-tikus jalanan. Pada kata tikus-tikus dalam dialog diatas menggabarkan seorang manusia yang sifatnya sama seperti tius yaitu licik dan orang yang bertindak kotor untuk penggabungan kata jalanan menggambarkan suasana yang bebas bergerak atau liar maka dari itu kata-kata tikus-tikus jalanan dalam dialog diatas bermakna yaitu sekelompok orang yang licik yang melakukan tindakan kotor atau para koruptor yang bebas berkeliaran.

b. Gaya bahasa personifikasi
Dalam film Dilan 1990 karya Pidi Baiq ini, bentuk-bentuk gaya bahasa bahasa personifikasi ada satu kutipan dialog sebagai berikut.

Kutipan 1.

"Milea 2"

"katakan sekarang!

Kalau kue kau anggap apa

dirimu?

Roti coklat? Roti keju?Martabak? Kroket? Bakwan

Ayolah, $\mathrm{Aku}$ ingin memesannya malam ini

Aku mau kamu

Dilan, Bandung1990 (pada menit ke-01:22:45).

Gaya bahasa personifikasi adalah gaya bahasa yang menggunakan sifat manusia pada benda yang mati dan solah hidup. Dalam kutipan dialog diatas gaya bahasa personifikasi yaitu pada kalimat Kalau kue kau anggap apa dirimu? Roti cklat? Roti keju?Martabak? Kroket? Bakwan. Penggunaan kata-kata Kalau kue kau anggap apa dirimu? Roti cklat? Roti keju?Martabak? Kroket? Bakwan tersebut seolah-olah membandingkan atau menggambarkan benda yang memiliki sifat seperti manusia.

c. Gaya bahasa litotes

Kutipan 1.

Masya Allah, Kenapa sih rumah

ini cantik-cantik semua 


\author{
yah?(pada menit ke- \\ 01:05:39)
}

Biasa aja, bilang terima kasih (pada menit ke-01:05:46)

Terima kasih (pada menit ke$01: 05: 48)$

Gaya bahasa litotes ialah bentuk penyampainya yang bersifat merendahkan diri lawan bicara sehingga bertetangan dengan kenyataan yang sebenarnya. Dalam kutipan dialog diatas dapat diketahui gaya bahasa litotes terdapat pada awalpada menit 01:05:46 Biasa aja. Penggunaan kata biasa ajamerupakan kata yang merendahkan diri lawan bicaranya.

d. Gaya bahasa ironi

\section{Kutipan 1.}

Bagus, karena kalau kalian semua

sudah tahu apa itu morfologi saya tidak jadi mengajar morfologi.

Hei!(pada menit ke-13:)

Gaya bahasa ironi adalah gaya bahasa yanag disampaikan bertentangan dengan fakta yang mana bermaksud untuk menyindir secara halus. Dalam kutipan dialog diatas dapat diketahui gaya bahasa ironi terdapat kalau kalian semua sudah tahu apa itu morfologi saya tidak jadi mengajar morfologi. Kalimat kalau kalian semua sudah tahu apa itu morfologi saya tidak jadi mengajar morfologi tersebut memiliki maksud menyidir secara halus kepada lawan tuturnya.

e. Gaya bahasa pleonasme

Kutipan 1.

Ya udah deh, aku pamit

duluan ya (pada menit ke-02:30)

Gaya bahasa pleonasme adalah gaya bahasa yang menggunakan sepata kata yang sebenarnya tidak perlu diulangi lagi karena kata-katanya sudah jelas.Dalam kutipan dialog diatas dapat diketahui gaya bahasa pleonasme terdapat pada kataduluan. Penggunan dari kata duluan seharusnya tidak perlukan lagikarena kata pamit sudah bearti akan pergi duluan.

\section{KESIMPULAN}

Berdasarkan hasil penelitian dan pembahasan diperoleh simpulan bahwa penggunaan gaya bahasa pada film Dilan 1990 karya Pidi Baiq terdapat 85 ragam gaya bahasa, yaitu gaya bahasa perbandingan, gaya bahasa pertentangan, gaya bahasa sindiran, gaya bahasa penegasan atau perulangan. Ragam gaya bahasa yang menujukan gaya bahasa perbandingan terdapat 30 kutipan dialog, gaya bahasa pertentangan terdapat 5 kutipan dialog, gaya bahasa sindiran terdapat 28 kutipan dialog selanjutnya 
gaya bahasa penegasan atau perulangan terdapat 22 kutipan dialog. Berdasarkan penelitian gaya bahasa yang paling dominan di film Dilan 1990 karya Pidi Baiq yaitu gaya bahasa perbandinganyang terdapat 30 kutipan dialog.

\section{DAFTAR PUSTAKA}

Agustina, J., \& Mardiana, M. (2019). Pengaruh film indie (independent) terhadap keterampilan menulis cerpen siswa kelas xi sma negeri 1 talang kelapa. Jurnal Pembahsi (Pembelajaran Bahasa Dan Sastra Indonesia), 9(2), 159-166.

Ardila, Ike. 2015. Analisis Gaya Bahasa dalam Novel 3600 Detik Karya Charon. Skripsi SI (belum diterbitkan). Palembang: Fakultas Keguruan dan Ilmu Pendidikan Universitas Persatuan Guru Republik Indonesia.

Arsyad, Azhar. 2017. Media Pembelajaran. Depok: PT Raja Grafindo Persada.

Faruk. 2012. Metode Penelitian Sastra. Yogyakarta: Pustaka Belajar. Hariyanto, Dwi Pitri. 2017. Gaya Bahasa Sarkasme pada Film The Raid. Skripsi S1 (belum diterbitkan). Mataram: Fakultas Keguruan dan Ilmu Pendidikan Universitas Mataram.

http://fkipunram.gd/ifkip3.php?ni $\mathrm{m}=\mathrm{E} 1 \mathrm{C} 110137$.

Keraf, Gorsy. 2010. Diksi dan Gaya Bahasa. Jakarta: Gramedia Pustaka Utama.
Muhammad. 2011. Metode Penelitian Kualitatif Bahasa. Yogyaakarta: Ar-Ruuz Media.

Nopitasari, Oppi dan Azizi, Fadli Hilmi. 2018. Pedoman Buku Cerdas Paduan EBI (Ejaan Bahasa Indonesia). Sidoarjo:Media Cerdas.

Nurgiyanto, Burhan.2014. Stilistika. Yogyakarta: Gadjah Mada Uniersity Press.

Ratna, Nyoman Kutha. 2009. Teori, Metode, dan Teknik Penelitian Sastra.Yogyakarta: Pustaka Belajar.

Satato, Soediro. 2012. Stilistika. Yogyakarta: Ombak.

Siswantoro. 2011. Metode Penelitian Sastra. Yogyakarta: Pustaka Belajar.

Suandi, F. (2020). Transformasi Novel ke Film 99 Cahaya di Langit Eropa karya Hanum Salsabila dan Rangga Almahendra. Jurnal Pembahsi (Pembelajaran Bahasa Dan Sastra Indonesia), 10(2), 173-186.

Sugiyono. 2016. Metode Penelitian Kualitatif. Bandung. Alfabeta.

Tarigan, Guntur Henry. 2009. Pengajaran Gaya Bahasa. Bandung: Angkasa.

Trianton Teguh. 2013. Film Sebagai Media Belajar. Yogyakarta: Graha Ilmu.

Pemungkas, Sri. 2012. Bahasa Indonesia dalam Berbagai Perspektif. Yogyakarta: Andi Publisher.

Yandianto. 2004. Apresiasi Karya Sastra dan Punjangga Indoenesia. Bandung: MS2 Bandung. 